\title{
AINDA SUSPIRA A ÚLTIMA FLOR DO LÁCIO?
}

\section{IS IT THE SIGHING OF “THE LAST FLOWER OF LATIUM”?}

\author{
Ricardo Luiz Silveira da Costa \\ ricardo@ricardocosta.com \\ Leticia Fantin Vescovi \\ leticiafbs@hotmail.com \\ Universidade Federal do Espirito Santo, Brasil
}

Resum: O trabalho pretende analisar a formação do português e seus paralelos literários e históricos em relação ao castelhano e ao catalão. Para isso, primeiramente realizamos uma breve contextualização da trajetória linguística e literária das línguas ibero-românicas, a fim de ressaltar as semelhanças e diferenças na Hispânia. Em seguida, abordarmos três autores que, entre os séculos XIV e XIX, destacaram e realçaram a língua portuguesa em seu próprio tempo: o Conde D. Pedro de Barcelos (I287-I354), com sua Crónica Geral de Espanha de 1344; o padre e jesuíta Antônio Vieira (I608-I697), com o Sermáa vigésimo do Rosário, e o poeta parnasiano Olavo Bilac (I865I918), com o poema Profissão de Fé.

Paraules clau: História da Literatura comparada, Castelhano, Catalão, Conde de Barcelos, Antônio Vieira, Olavo Bilac.

Abstract: The work analyses the formation of the Portuguese language and its literary and historical parallels with Castilian and Catalan. With this aim, we first contextualize the linguistic and literary trajectory of Iberian-Romance languages, in order to highlight similarities and differences in Hispania. As case studies, we consider three authors who elevated and enhanced the Portuguese language of their own time: Pedro de Barcelos (1287-1354), with Crónica Geral de Espanha de 1344, the Jesuit and priest Antonio Vieira (I608-1697), with Sermáo vigésimo do Rosário, and the Parnassian poet Olavo Bilac (1865-1918), with the poem Profissão de Fé.

Key words: Comparative History of Literature, Castilian, Catalan, Count D. Pedro de Barcelos, Antônio Vieira, Olavo Bilac. 


\section{RICARDO DA COSTA \\ LETICIA FANTIN VESCOVI}

\section{AINDA SUSPIRA A ÚLTIMA FLOR DO LÁCIO?}

Última flor do Lácio, inculta e bela, Es, a um tempo, esplendor e sepultura:

Ouro nativo, que na ganga impura A bruta mina entre os cascalhos vela... Amo-te assim, desconhecida e obscura,

Tuba de alto clangor, lira singela, Que tens o trom e o silvo da procela E o arrolo da saudade e da ternura!

Amo o teu viço agreste e o teu aroma De virgens selvas e de oceano largo! Amo-te, ó rude e doloroso idioma, Em que da voz materna ouvi: "meu filho!" E em que Camóes chorou, no exilio amargo, O gênio sem ventura e o amor sem brilho!

Olavo Bilac (1865-1918), Lingua portuguesa.

\section{DESCONSOLO IRREMEDIÁVEL}

Lá se vão quase cem anos desde a morte de Olavo Bilac, nosso mais ilustre poeta parnasiano, dentre todos, um de nossos preferidos. Hoje, com a (aparente) inexorável decadência das Letras e da Educação no Brasil, não é sem saudade no coração que 
recordamos que, na distante primeira metade da década de 70, tão pouco tempo atrás, as aulas de Literatura de Segundo Grau realmente algo ensinavam aos jovens brasileiros. Nostalgia do passado. Lamento. Saudade. Há sentimento português mais genuíno? Dor da ausência e comprazimento da presença, pela memória. Um não querer assumir plenamente o presente nem reconhecer o passado como pretérito. Desnorteante e paradoxal, o amor à portuguesa se compraz na distanciação. Misto de sensualidade insatisfeita e espiritualidade impura, esse espírito presente na língua denota tanto uma afetividade complexa no plano pessoal quanto a obliquidade das relaçóes no plano social. Nossa língua traz esses desconcertos consigo. ${ }^{1}$ Nós, estudantes, ainda aprendíamos um pouco das bases culturais de nossa história, de nossas letras, de nosso passado. Um pouco. Ainda não havíamos experimentado a monstruosa implementação da engenharia social pedagógico-construtivista que, logo a seguir, solaparia nossa cultura.

Hoje, em meio a ruínas e desolação, ao caos linguistico-gramatical táo sonhado e apregoado por Paulo Freire (I92I-I997), maldito pedagogo do Apocalipse, ${ }^{2}$ escrevemos essas poucas palavras a respeito da formação do português como língua literária para atender a um honroso convite, feliz porém imerso na triste constatação do quase absoluto desconhecimento da cultura brasileira/portuguesa por parte dos estudantes de seu país. Nossa sensação, misto de angústia e solidão, é semelhante à do escritor franco Gregório de Tours (c. 539-594) que, ao redigir sua História dos Francos no distante século vi, lamentou (I999 [ $\mathrm{I}^{\mathrm{a}}$ ed c. 59I]: 3I): «Maldita a nossa época, pois o estudo das letras está morto entre nós». Lamentamos do mesmo modo: maldita seja nossa época na qual, via de regra, muitos estudantes de letras não sabem escrever, tantos historiadores desconhecem a história, os geógrafos a geografia, os arquitetos a arquitetura, os artistas a arte. Sim, até tu, arte, foi relegada ao lixo experimental do grotesco. ${ }^{3}$

Mas nosso desconsolo com a decadência não é original. Petrônio (c. 27-66) já fez o mesmo - e suas palavras soam atualíssimas no mundo do lado de baixo do Equador:

$$
\begin{aligned}
& \text { LXXXVIII } \\
& \text { Mergulhados em vinhos e prostitutas, não ousamos sequer conhecer as artes apropriadas } \\
& \text { e, como delatores da Antiguidade, ensinamos e aprendemos apenas vícios. Onde está a Dialética? } \\
& \text { Onde está a Astronomia? Onde está o caminho esmeradíssimo da Sabedoria? } \\
& \text { (in Petrônio } 2004 \text { [I } \mathrm{I}^{\mathrm{a}} \text { ed c.60]: 153). }
\end{aligned}
$$

I. Baseado em Saraiva (1994: 84-86).

2. Cujas fundamentaçóes básicas encontram-se em Freire (2005 [ [ ${ }^{\mathrm{a}}$ ed 1968$\left.]\right)$.

3. Para o tema, ver Scruton (2009). 
Reiteramos: onde? Em nossa história literária. Na solidão de nossas memórias, com a companhia de nossos livros e a transcendência da música clássica mozartiana como pano de fundo sonoro, ${ }^{4}$ desejamos com esse modesto opúsculo resgatar um pouco de sua trajetória. De sua construção. Ademais, também foi-nos solicitado que a relacionasse com a formação do cataláo e do castelhano. Embora hesitantes quanto às nossas forças intelectuais, aceitamos o convite e, para correspondê-lo, basear-nosemos em alguns exemplos históricos extraídos de expoentes sublimes das línguas em questão. No tocante ao contraste entre elas, perceberá o leitor que esforçamo-nos por relacioná-las literariamente e compará-las, vez ou outra, linguisticamente. Comecemos então, como de hábito, pelo começo.

\section{DIFERENÇAS NA HISPÂNIA: O FIN'AMORS DAS CANTIGAS GALEGO- PORTUGUESAS}

Bela, natural e popular criação das sociedades humanas, a língua é fruto de um conjunto de transformaçóes consecutivas de geraçóes que, unidas em uma linha temporal e em um espaço geográfico comum, orientam criativa e coletivamente suas expressóes orais e escritas. Trata-se de uma expressão estética dos sentimentos e pensamentos de um povo, elo primeiro de ligação, manifesto palpável de uma cultura.

Nas terras da Hispânia, veem-se os frutos de sua rica história em uma pluralidade linguística que ora acentua, em razão de uma mesma raiz latina, as semelhanças culturais entre seus povos, ora os distancia em razão de caminhos linguístico-evolutivos nem sempre alheios à interferência política e social.

A trajetória das línguas ibero-românicas — português, galego, espanhol e cataláo - tem sua raiz, inicialmente, na crescente dialetaçáo do latim vulgar nos extremos do Império romano e, posteriormente, na fragmentação da unidade política imperial. Remontando-nos à romanizaçáo ibérica (2I8-219 a.C.), percebemos que o próprio movimento colonizador latino promoveu uma evolução linguística com ritmo e nuances distintos nos grupos sociais do Centro e do Nordeste da Península. A esse exemplo, em virtude dos dois pólos geográficos de expansão da conquista romana — o primeiro ao nordeste, pelo vale do Ebro (até as Astúrias) e o outro ao sul (pelo Guadalquivir, em

4. Nos passos do historiador espanhol Ruiz-Domènec (20II). 
direção ao norte) — a Hispânia fora dividida em Citerior e Ulterior, e nessa última, colonizada por latinos do sul da Itália.

Em relação ao desenvolvimento do galego-português, há um marco hidrográfico, todo o norte do Douro. Ali, ao final do século x, surgiram os primeiros documentos, em um latim barbarizado, nos quais caracteres galego-portugueses já se distinguiam dessa cepa linguística. Como Georges Duby (I988: I) afirmou que a primeira obrigação do historiador, sua principal atividade, é a imaginação, podemos, por um vislumbre, devanear a doçura paisagística das azenhas que, lentamente, começavam a ser difundidas naqueles tempos distantes, quando então a imagem da sociedade feudal adquiria seu traço mais característico. ${ }^{5}$

Seus moinhos d'água, com sua sonoridade monocórdia porém paradisíaca, formaram o harmônico pano de fundo que deu ao português, posteriormente, seu traço mais melancólico. Somados a eles, os arados que cortavam a terra lusitana. De acordo com o especialista Jorge Dias (1948), três foram os tipos de arado que ajudaram a definir três tipos de vertentes da cultura lusitana no recanto da Península: I) o arado radial (ou lusitano, porque oriundo da Lusitânia romana), 2) o arado de garganta (do trigo, irradiado a partir da Andaluzia, e 3) o arado quadrangular (ou arado suevo, útil para a cultura do milho).

Além dessa irradiação cultural/linguística entre a terra e os homens, a formação do galego-português seguiu quase pari passu à do castelhano, tanto no que diz respeito aos primeiros registros escritos, ao final do século $\mathrm{x}$, quanto ao grau de inteligibilidade entre seus falantes. $\mathrm{O}$ catalão, um pouco à margem dessa reciprocidade linguística, apresenta maior afinidade lexical com as línguas galo-românicas e, inclusive, no que diz respeito a essa mútua compreensão, relaciona-se mais intimamente com o occitano que o castelhano com o galego-português. ${ }^{6}$

É preciso considerar, antes de mais nada, que entre o fim do século XII até meados do XIV as diversas casas reinantes na Península — Leão, Castela, Aragão e Catalunha, Navarra e Portugal - mantinham vínculos estreitos entre si e não raras vezes poetas profissionais iam de uma corte a outra oferecendo sua arte. Embora em cada regiáo florescessem línguas autônomas, deu-se a escolha do galego-português para veículo

5. Ver o clássico de Baldinger (1963) e também Caplletra 5I (20II).

6. Alguns linguistas acreditam que o occitano e o cataláo sejam variedades de uma mesma língua. Outros, ademais, consideram que essa estreita relação os distingue, junto ao gascão, em um novo grupo linguístico, o occitano-românico. 
de expressão de toda a lírica peninsular. ${ }^{7}$ Muitos estudiosos, como Maleval, Mongelli e Vieira (1992), conquanto não sejam concretas as hipóteses acerca da preferência, atribuem essa escolha ao intenso intercâmbio cultural de Santiago de Compostela, na Galiza, rumo final dos cristãos que seguiam os chamados Caminhos de São Tiago a fim de venerarem o túmulo do apóstolo.

Todavia, se por um lado, nas proximidades do Atlântico notamos o fortalecimento de uma língua por um viés político-cultural, por outro, no istmo dos Pirenéus, é patente a precocidade expressiva do catalão em relação às irmãs peninsulares. $\mathrm{E}$ isso não só em virtude de seus primeiros registros escritos remontarem um século aos do castelhano e do galego-português, mas, principalmente, por seu contato primevo com o lirismo provençal, cujos trovadores ensinaram toda a Europa a amar. ${ }^{8} \mathrm{~A}$ língua catalá, por sua localização geográfica, teve o privilégio de ser a primeira apreciadora do fin'amors. ${ }^{9}$

Gostaríamos, assim, de iniciarmos nossas consideraçôes literárias citando um poema de um anônimo enamorado de Ripoll ${ }^{10}$ (séc. XII), texto dedicado à condessa de França, que revela, além da clara influência dos Cânticos de Salomão, ${ }^{11}$ a notável plasticidade da língua, mesmo em seu nascedouro:

7. Era esse galego-português, contudo, diferente da variedade vulgar falada no noroeste da Península. Seu uso assemelha-se mais ao de uma koiné, no âmbito literário.

8. Indicam as autoras acima a obra de Frappier (1973) sobre o tema.

9. Para um aprofundamento sobre o amor como impulsionador da língua catalâ, ver Hatem (20II).

Io. Para o tema, indicamos Moralejo (1973; 1986).

II. Agradecemos a observação feita por Francis Rasseli. 
Com estrelles té el cel, l'aigua peixos, cossos la terra, vinguin a tu tants o més mots de salutació.

Bella fins a l'excés, a ningú més comparable, ¿quina necessitat tens dels adorns elegants?

Les pedreries i l'or no et fan pas ser més bonica: ets molt més bella tu que els diamants i que l'or.

I si el coll de neu amb brillants joiells et guarnies, els joiells són brillants per la blancor del teu coll.

Digue'm: ¿pot cap vel embellir uns cabells tan formosos que ni els de Febus mateix no sabran igualar?

Quan et poses l'anell al dit delicat, aleshores l'or i la pedra són per aquest fet molt més bells.

És radiant el tel front: si el sol patia un eclipsi, el gran dia pots fer retornàamb el teu front.

I tens blanques les dents, centellejant la mirada, i unes cames molt més refulgents que la neu.

La formosor dels teus pits és digna de tota lloança: els teus pits petits són més brillants que la neu.

No ets gaire alta; la forma del teu peu és bem xica: tens un peu molt petit, i és agradable a tothom.

Soles, no se t'assemblen pas ni Diana ni Venus: elles només ensems són comparables a tu.

Ets més bella que Venus i més radiant que Diana: plau a Diana el que és bell, Venus domina en candor.

Tot el que es veu arreu, la teva bellesa ho supera, car enlloc no hi ha res que se't pogués comparar.

França, que en tens, de sort: tu serves la flor de les dones; m'agradaria ser fill d'un país com aquest.

(in Serta 2008-2009: I9I-I92)
Como estrelas tem o céu, peixes a água, corpos a terra, que venham a ti tantas ou mais palavras de saudação.

Excessivamente bela, incomparável, que necessidade tens de adornos elegantes?

As pedras e o ouro não te tornam mais bonita: és muito mais bela que os diamantes e o ouro.

E se adornas teu colo de neve com brilhantes jóias, são elas brilhantes pela brancura do teu colo.

Diga-me: pode algum véu embelezar cabelos tâo formosos que nem os de Febo podem igualar?

Quando colocas um anel em teu delicado dedo, o ouro e a pedra são por isso muito mais belos.

Tua fronte é radiante. Caso o Sol sofresse um eclipse, poderias fazer retornar aquele grande dia com tua fronte.

Tens os dentes brancos, cintilante é teu olhar, e tuas pernas, muito mais refulgentes que a neve.

A formosura de teus seios é digna de todo louvor: são eles mais brilhantes que a neve.

Náo és muito alta, e a forma de teu pé é bem pequena. Tens um pé pequenino, agradável a todos.

Única, não te assemelhas nem a Diana, nem a Vênus: elas somente são comparáveis a ti.

És mais bela que Vênus e mais radiante que Diana: agrada à Diana o que é belo, Vênus dominas com candura.

Tudo o que se vê ao redor, tua beleza supera, pois em nenhum lugar há nada que se possa comparar.

Por sorte, França te tens: tu serves como uma flor às senhoras; agradar-me-ia ser filho de um país como esse. $^{12}$

I2. Tradução de Ricardo da Costa. 
Cortês e submisso, o anônimo enamorado não poupa elogios à sua amada, simbolizando-a por uma claridade ofuscante. Sob à égide desta bela senhora, indubitavelmente superior à mais bela tríade do panteão grego, não hesita em matizar com branda sensualidade o poema: colo e pernas, de nevada brancura, dizem respeito ao que de fato viu ou ao que não pôde deixar de imaginar? Quáo «ousado» é este cataláo em relação àquele galego-português, renunciante, lamentoso e paradoxal, que sempre lança máo em suas cantigas de um querer e náo querer, de um desejo preso à coita amorosa!

A joi occitânica e a esperança da recompensa, conceitos fundamentais do fin'amors, ${ }^{13}$ tornaram-se pálidas na cantiga galego-portuguesa, que intensificou a fatalidade e a inacessibilidade à dama do código do amor provençal. Por ter sido um ramo tardio e marginal da lírica occitânica, forjada sob uma dupla recepção, da língua d’oc e do modus vivendi do sul da França, a lírica galego-portuguesa absorveu-as de modo autóctone, certamente influenciada pelo substrato social no qual fundara-se (Maleval, Mongelli \& Vieira 1992: 38). Sua forma primitiva é, de fato, um grito de amor infeliz ecoando de estrofe em estrofe (Lapa I981: 146). D. Dinis, nesta bela cantiga, dá-nos uma mostra do pendão quase mortal que guia o apassionado:

Un tal ome sei eu, ai, ben talhada, que por vós ten a sa morte chegada; vedes quen é e seed' em nembrada; eu, mia dona!

Un tal ome sei eu, que preto sente de si morte chegada certamente; vedes quen é e venha-vos em mente: eu, mia dona!

Un tal ome sei eu — aquest' oíde que por vós morre, vó-lo en partide; vedes quen é e non xe vos obride: eu, mia dona!

I3. Também conhecido como amour courtois, ou amor cortês, conceito europeu medieval responsável pela difusão das regras da disciplina amorosa na literatura mundial. Para uma definição completa, recomendamos a busca do conceito "Amor" em Spina (1996). 
As frequentes repetiçóes em nosso lirismo, segundo Manuel Lapa (I98I: I40), explicam-se pela necessidade tautológica de exalar, em um suspiro, as queixas contra aquele dom inalcançável. Soa-nos esses paralelismos, é verdade, como obsessão, e talvez por isso mesmo os trovadores, a fim de evitarem o fastio, tenham limitado suas cantigas a três ou quatro estrofes. Mas nesse turbilhão de emoçôes não se mostram desordeiros, impetuosos, não ousam macular sua senhora. Sofrem a coita pacientemente, fineza de porte aprendida com a mesura provençal.

Alheio a essa passional sintomatologia, o enamorado de Ripoll escapa àquela impediente correspondência amorosa tão frequente nos coraçôes portugueses. Ele insinua sua lástima de modo mais leve, deixando entrever, à sombra de uma condicionalidade verbal tenuamente empregada em seu último verso, um convite ao amor.

Mas servem ambos, é verdade, as suas senhoras, como um vassalo serve ao suserano, fiel e diligentemente. A quintessência do Trovadorismo ibérico reside nessa lealdade que, esquecida de brasóes e espadas, une todos os homens na figura de um mesmo senhor. Todos são reis, cavaleiros e camponeses: reis pela nobreza (de sentimento), cavaleiros pela coragem (da corte), camponeses pela submissão (à amada). E por este tom cavalheiresco a literatura portuguesa trilhou seu caminho. Mas adiantemos o passo, e observemos como amadureceu a língua em sua prosa literária.

\section{AINDA QUE RUDE, O PORTUGUÊS COMO LÍNGUA MADURA: A CRÓNICA GERAL DE ESPANHA DE 1344}

A separação definitiva entre o galego e o português teve início com a independência de Portugal, em II85, e consolidou-se com a expulsão dos mouros (em I249) e a resistência contra a anexação castelhana do país, em 1385 .

Em I297, findado o processo de Reconquista, D. Dinis (c. I26I-I325), monarca e grande mecenas da literatura trovadoresca, adotou o português como língua do reino de Portugal, assim como seu avô Afonso X, o Sábio (I22I-I284), monarca de Leão e Castela, anos antes fizera com o castelhano, ao mandar redigir na língua grandes obras históricas, astronômicas e legais..$^{14} \mathrm{O}$ caráter oficial possibilitou ao português

I4. Para um estudo das Cantigas de Santa Maria, ver os artigos inéditos gentilmente cedidos pelos autores, R. Costa e B. Dantas, 'A falsidade dos judeus é grande’: uma representação de judeus nas Cantigas de Santa 
seu desenvolvimento autônomo em relação ao galego, língua esta que, em virtude da expansão territorial portuguesa e da dominação castelhana, perdeu a importância literária de outrora. ${ }^{15}$

A prosa literária viu nascer, então, em português genuíno, a Crónica Geral de Espanha de 1344, de D. Pedro (c. I287-I354), conde de Barcelos e filho bastardo de D. Dinis. Baseado na Crónica Geral de Afonso X (tradução galega da variante ampliada de 1289 feita pelo próprio conde) e na Crónica do Mouro Rasis (traduzida no mesmo período por mestre Maomet e Gil Peres, clérigo de seu sogro, Pero Anes de Portel, a pedido de D. Dinis), trata-se de um importantíssimo texto que mostra o interesse da corte portuguesa pela história da Espanha na primeira metade do século XIV (Saraiva I988: I59). Há, nele, valiosas informaçóes sobre o reinado de D. Dinis e de Afonso IV $\left(\right.$ I29I-I357). ${ }^{16}$

Nosso périplo continua com uma breve e voluptuosa passagem da vida de Afonso VIII narrada na Crónica (Cintra I99I: 28I-282): seu casamento com Leonor Plantageneta (II62-I2I4) e sua paixão por uma judia:

Depois que el rey dó Afonso ouve assessegado seu reyno, fez suas cortes en Burgos e foron en ellas juntos todolos altos homèes de seu senhorio e outrossy os prellados e homēs bóos dos concelhos. E foy en ellas acordado que, pois já el rey era homen de doze annos, que o casassem. Entom mandarô per seus embaxadores a el rey d'Ïgraterra pedir húa sua filha que avya nome dona Lyonor e era moça de nove annos.

\section{$[\ldots]$}

Despois que el rey dom Afonso foy casado como já ouvistes, esteve en Burgos quanto tempo lhe prouve e despois pera Tolledo con sua molher. E estando hy, vyo húa judya que era mui fremosa e pagousse tanto della que leixou a raynha, sua molher, e eç̧arrousse có a judya hûu grande tempo, en tal guisa que o non podyam della partir nem se pagava tấto doutra cousa

Maria (séc. XIII). Disponível em: <http://www.ricardocosta.com/artigo/falsidade-dos-judeus-e-grande-umarepresentacao-de-judeus-nas-cantigas-de-santa-maria-sec>; R. Costa e B. Dantas, «Bondade, Justiça e Verdade. Três virtudes marianas nas Cantigas de Santa Maria e no Livro de Santa Maria, de Ramon Llull». Disponível em: $<$ http://www.ricardocosta.com/artigo/bondade-justica-e-verdade-tres-virtudes-marianas >.

I5. Os séculos XV e XviıI são chamados Séculos Escuros por representarem um período de obnubilação da língua galega, cujo brilho faz-se admirar novamente no século xIx, Rexurgimento, que, vale pontuar, coincide temporal e objetivamente com a Renaixença catală.

I6. Por sua vez, na Coroa de Aragão, a obra histórica gótica (De rebus Hispaniae) do arcebispo de Toledo D. Jiménez de Rada (II70-I247), escrita a pedido do rei Fernando III de Castela, o Santo (II99-I252), também foi muito influente na historiografia posterior. 
como della. E, segundo conta o arcebispo dom Rodrigo, esteve ençarrado con ella sete meses, assi que se non nembrava de sy nem de seu reyno nem de outra cousa. E dizem algúus que este tam grande amor que elle avya a esta judya que non era se non por feitiços que lhe ela sabya fazer.

(caps. DCCXL-DCCXLI)

Concomitantemente à Crónica, também Castela viu surgir, pelas mãos de Juan Ruiz, Arcipreste de Hita (c. I284-135I), uma das obras mais importantes da literatura castelhana do século XIv, El libro de buen amor. ${ }^{17}$ Miscelânea lírica de métrica varia$\mathrm{da}$, tem por temas alguns exempla portadores de ensinamentos morais, ${ }^{18}$ narraçóes de amores, disputas alegóricas, sátiras anticlericais de tom goliardesco, serranilhas (cançôes pastorais) e composiçóes líricas em louvor à Virgem Maria, unidas todas por um único fio condutor, a pretensão de ser uma verdadeira autobiografia. Pretensa, fictícia, pois ainda que tenha narrado em primeira pessoa ou utilizado recordaçóes de experiências juvenis, Juan Ruiz nem sempre preocupou-se em retratar-se a si mesmo, senão personagens imaginários de seus relatos (Puyol 1906: 106). O amor, em suas mais variadas matizes - carnal, cortês, místico — é o motor dessa produção textual castelhana. Seu estilo embebido de múltiplas fontes ${ }^{19}$ e seu léxico extraordinário, os instrumentos pelos quais a ironia e o chiste chegam a seu leitor. Para que o leitor entre em contato com essa maravilhosa obra de arte castelhana, recortamos da obra os versos 77 a 84, sobre cómo el arcipreste fuer enamorado:

\footnotetext{
Así fuer que un tiempo una dueña me priso, de su amor non fuy en ese tiempo repiso, siempre avía d'ella buena fabla e buen riso, nunca ál fiso por mí, ni creo que faser quiso. Era dueña en todo, e de dueñas señora, non podía estar solo con ella una hora, mucho de omen se guardan allí do ella mora; más mucho que non guardan los jodíos la Tora
}

17. Nenhum dos manuscritos da obra possui título. O que hoje conhecemos foi proposto em I898 por Ramón Menéndez Pidal (1869-1968).

I8. Menéndez Pidal foi o primeiro autor, em seu livro Poesía juglaresca y origenes de las literaturas europeas, a insistir na atitude satírica de Ruiz frente à antiga tradição didático-moral da época.

19. Tarefa árdua seria, em um rodapé, enumerar todas as fontes literárias do Libro de buen amor, além de sua métrica, conteúdo e estrutura pormenorizados. Para aprofundamento, recomendamos a leitura de Puyol (I906) e de los Ríos (I86I). 


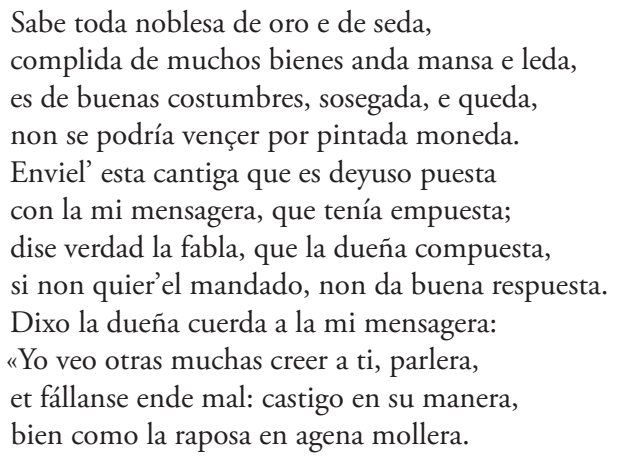

Cumpre destacar que o mester de clerecía revela sua paixão por uma dama mansa, de buen riso, buena fabla, curiosamente as exatas características que outrora D. Dinis dissera se tratarem de acessório estrangeiro no lirismo galego-português (Lapa 198I: I45), sem dúvida advindo de empréstimo provençal. A escolha adjetiva denuncia-nos, sutilmente, a conclusão para a qual os estudiosos do livro (e da literatura hispânica em geral) convergem: a inegável influência francesa no estilo e na matéria da literatura de Juan Ruiz e de toda a Península Ibérica.

O Arcipreste, como se vê, não escapou de um infeliz desenlace. A moça, rejeitando-o, infligiu-o um castigo por seu falar descomprometido e mui galanteador. Seu fim, todavia, nem de longe se compara ao trágico da «judia feiticeira» de Afonso VIII: os condes, cavaleiros e ricos-homens do reino decidiram degolá-la. Inconsolável, o rei recebeu a visita de um anjo, que lhe admoestou (Cintra 1991: 282-283):

- E como, Afonso, ainda estás cuidando no mal que has feito, do qual Deus recebeu gram desserviço? Mal fazes, ca sabe por certo que caramente o demandará a ty e ao teu reyno (...) E, por este pecado que tu fezeste, non ficará de ty filho que reyne no logar que tu reynas, mas ficará do linhagen de tua filha. E, daquy adeante, partete de mal obrar e non faças cousa por que Nosso Senhor tome de ty mayor sanha.

$\mathrm{E}$, logo que lhe esto ouve dito, desapareceo e ficou a camara comprida de maravilhoso odor e con grande claridade. Mas el rey ficou muy triste por o que lhe disse o angio e des aly adeante andou nos caminhos de Deus e fez boas obras e emendou muito en sua fazenda, como adeãte ouvirees.

(cap. DCCXLI).

O desvario do rei, «enfeitiçado" pela judia, mostra que, desde cedo, a percepçáo das paixôes desenfreadas eram condutoras da historiografia portuguesa. Escrita em 
um tempo em que as palavras tinham uma relaçáo quase direta com as coisas da vida, unívoca, a Crónica de 1344 finca seu pé na perspectiva hispânica dos acontecimentos. Portugal é Portugal, mas integrante do conceito romano da Hispânia — além de inserido na amplidão da Christianitas. ${ }^{20} \mathrm{~A}$ língua portuguesa, ainda rude, passara a acolher a História. Nos séculos posteriores, transforma-se em porta-voz de um novo sentimento: o orgulho de uma identidade nacional portuguesa.

\section{SALTO PARA O MUNDO: ANTÔNIO VIEIRA E O FIM DA RUSTICIDADE}

«Apliquemos nosso trabalho a nossa língua e gente e ficará com maior eternidade a memória dele e não trabalhemos em língua estrangeira, mas apuremos tanto a nossa com boas doutrinas, que sempre a possamos ensinar a muitas outras.»

Fernão de Oliveira, Grammatica da Lingoagem Portuguesa (1974 [Iª ed. 1536]: 34)

O primeiro passo literário para a abertura da língua portuguesa para o mundo, para o fim da rusticidade literária, o fim do sentimento provinciano - ou, segundo Jacques Le Goff (1983: 57), «mentalidade de capela»; ou ainda, de acordo com Saraiva, o "aldeanismo" (I944: IO4) - deu-se com a expansão ultramarina. Nesse período histórico (entre os séculos XVI e XVII) a língua foi adornada, polida, esmerada e, para o gozo de nossa história, apresentada aos índios da terra de Vera Cruz.

Nesses novos territórios, nós, sul-americanos, alheios à marcha da evolução natural europeia, conservamos algumas características linguísticas destes tempos que, depois, Portugal e Espanha abandonaram. À guisa de exemplo, percebemos que o português europeu proporciona hoje ao falante uma atitude linguística introvertida, assaz diferente da riqueza teatral do português brasileiro (e mesmo do espanhol, do italiano e do francês). O lento e secular apagamento de suas vogais contribuiu para essa impressão de acanhamento sonoro. Recitar Camóes (c. I524-I580) exige uma sonori-

20. Essa paixão do rei Afonso VIII pela judia recorda a do rei Jaime I por D. Berenguela Afonso, filha de Afonso de Molina (c. I203-I272), infante de Castela e Leão e irmão de Fernando III (I2OI-I252). No entanto, ao contrário da viva e apaixonada descrição do romance de Afonso VIII, Jaime I dedica poucas palavras a Berneguela - e em tom de penitência: «O bispo de Barcelona andava conosco, e perguntamos pelo frade Arnau de Segarra, que era pregador; e dissemos que desejávamos nos penitenciar com ele. Ele disse que o fizéssemos. Nós dissemos que não pensávamos ter cometido outro erro com Nosso Senhor que devêssemos estar perdidos, a não ser com Dona Berenguela, mas que tínhamos a intenção de estar com ela sem pecado, assim como um homem deve estar com sua mulher» Livro dos Feitos, cap. 355 , $\$ 426$, p. 383 (ed. Ferrando). 
dade que o português coetâneo de Portugal mal suporta e que o português brasileiro, de fato, suaviza musicalmente. Somada a essa introspecção sonora, a instabilidade da escrita: só em I9II o estado português nomeou uma comissão para estabelecer uma ortografia fonética - trabalho incompleto em sua lógica.

De modo análogo, o castelhano das chamadas zonas de seseo - Andaluzia, Canárias e Hispano-américa — não acompanhou o processo de evolução fonética das consoantes sibilantes do castelhano peninsular, cuja insistente posposição do ponto de articulação da pronúncia do $/ \mathrm{s} /$ culminou no moderno som interdental $/ \theta / .{ }^{21}$ Qual riqueza linguística não imaginaríamos se a língua catalâ, geograficamente limitada para tais aventuras, também tivesse cruzado os mares!

A difusáo luso-hispânica de séculos atrás, de fato promotora dessa curiosa semelhança fonética entre castelhano e português subtropicais e seus pares medievais, deu impulso também ao surgimento das primeiras gramáticas e lexicógrafos em ambas as línguas. Todavia, não havendo reino que se sustente sem que haja zelo pelo império das palavras, pôde considerar-se o português privilegiado, pois, à época, Luís de Camóes presenteou-nos com a epopeia portuguesa por excelência, Os Lusíadas, além de poesia embebida de trovadorismo e comédias de inspiração clássica. Não à toa, costumamos dizer que nossa língua é, antes de tudo, sua. Mas essas breves palavras sobre o ilustre poeta indicam, paradoxalmente, que dele fugiremos. Em verdade, não por desconsideração, mas por uma ainda não superável incapacidade artístico-interpretativa.

Escolhemos, pois, seguir viagem em companhia do escritor-símbolo do Barroco português, do maior orador das letras sagradas, homem embebido do Humanismo clássico somado aos valores da Contra-Reforma, o padre e jesuíta Antônio Vieira (I608-1697). Seus sermões são pérolas da língua, um Himalaia de inumeráveis cumes imponentes. Quanto aos conceitos, alguns dos Sermóes possuem aquela força avassaladora do claro-escuro, táo tipicamente barroca. Forma e conteúdo estão ali em sintonia perfeita. ${ }^{22}$ Selecionamos apenas extratos de um (Sermão vigésimo do Rosário), ${ }^{23}$ sobre os brancos, os pretos e os pardos, tema atualíssimo para a historiografia do politicamente correto, que hoje insiste em inventar um passado que nunca existiu e que serve apenas a interesses políticos coetâneos. ${ }^{24}$

2I. Pronunciado como o th em think, no inglês.

22. Maravilhosa frase de Sidney Silveira, a quem agradeço a generosidade da cessão.

23. Presente em Bosi (20II: 207-245).

24. Para o tema, ver Costa (2008: 43-70). 
O ponto de partida do sermão do jesuíta é uma passagem de Mateus (I, 2): Jacó gerou Judá e seus irmãos (Jacob autem genuit Judam, et fratres ejus). Todos somos filhos de Deus. Filhos do primeiro soberbo. Deus nos criou da mesma massa, para que vivêssemos unidos, mas não o somos; para que fôssemos iguais, mas nos desigualamos; para que fôssemos irmãos, mas desprezamos nosso parentesco:

O domingo passado, falando na linguagem da terra, celebraram os brancos a sua festa do Rosário, e hoje, em dia e ato apartado, festejam a sua os pretos, e só os pretos. Até nas cousas sagradas, e que pertencem ao culto do mesmo Deus, que fez a todos iguais, primeiro buscam os homens a distinção que a piedade. [...] Não há, nem deve haver distinção de escravo a senhor, nem de cativo a livre [...] Isto é o que ensina o Evangelho; mas o que vemos na nossa república, não em alguns, senão em todos, é tudo o contrário (I).

Assim, diante de uma plateia composta por ambas as irmandades, Vieira apresenta sua disputatio sermocional:

Suposta pois esta distinção e separação de irmandades, uma dos brancos, outra dos pretos; uma dos senhores, outra dos escravos; o meu assunto, ou questão, muito digna de se disputar, será hoje esta: Qual destas duas irmandades é mais grata, e mais favorecida da Mãe de Deus: Se a dos pretos, ou a dos brancos; a dos escravos, ou a dos senhores? Uns e outros estão presentes, e a todos toca igualmente ajudarem-me a pedir a graça (I).

O que realmente importa é: quem tem o amor da Virgem? Vieira apresenta as causas da hierarquia social da Terra brasilis:

Três causas têm nesta nossa república, os que se chamam senhores, para a grande distinção que fazem entre si, e os seus escravos. $\mathrm{O}$ nome, a cor, e a fortuna. $\mathrm{O}$ nome de escravos, a cor preta, e a fortuna de cativos, mais negra que a mesma cor. Agora veremos se são bastante estas três causas, para que na estimação da soberana rainha dos anjos tenham melhor lugar os senhores que os escravos, os brancos que os pretos, e a humilde fortuna desta segunda irmandade, que a nobreza da primeira (II).

Vieira ressalta a condição escrava de Nosso Senhor: enquanto Filho do Pai, Ele é Senhor dos homens; mas enquanto Filho de sua Mãe, Ele quis a mesma Mãe que fosse também escravo dos mesmos homens. Por isso, diferentes são os olhos de Deus dos olhos dos homens. Pois se Deus não pôs os olhos na majestade e grandeza das senhoras, senão na humildade e baixeza da escrava, certamente têm os escravos, em comparação de seus senhores, o maior favor e agrado dos olhos da Mãe de Deus. Nigra sum, sed formosa (Ct I, 5). Deus estima os pretos: 
Entre os homens dominarem os brancos aos pretos, é força, e não razão ou natureza [...] ninguém haverá que não reconheça e venere na cor preta duas prerrogativas muito notáveis. A primeira, que ela encobre melhor os defeitos, os quais a branca manifesta e faz mais feios; a segunda, que só ela não se deixa tingir de outra cor [...] Os filósofos dizem que a cor preta é próprio unir a vista, e da branca disgregá-la e desuni-la. Por isso a brancura da neve ofende e cega os olhos. E não é isto mesmo o que com grande louvor dos pretos, e não menor afronta dos brancos, se acha em uns e outros? Dos pretos é tão própria e natural a união, que a todos os que têm a mesma cor, chamam parentes; a todos os que servem na mesma casa, chamam parceiros; e a todos os que se embarcaram no mesmo navio, chamam malungos. ${ }^{25} \mathrm{E}$ os brancos? Não basta andarem meses juntos no mesmo ventre, como Jacó e Esaú, para não se aborrecerem [...] (V).

Deus não é como os homens, porque os homens olham para o rosto, para as aparências, e Ele para os coraçôes (ISm I6, 7). E que os brancos, com sua brancura só por fora, sejam negros por dentro.

A última razão — ou sem-razão — para que os senhores desprezem seus escravos é a vileza e miséria de sua fortuna. Nesse momento de seu sermão, Vieira faz eco à tradição medieval, herdeira de Boécio (c. 480-525), e se vale da recorridíssima imagem da Roda da Fortuna:

Oh Fortuna! E que mal considera a cegueira humana as voltas da tua roda? Virá tempo, e não tardará muito, em que esta roda dê volta, e então se verá qual é a melhor fortuna, se a vil e desprezada dos escravos, ou a nobre e honrada dos senhores (VIII).

A admoestação termina com uma advertência, incitação à superioridade da consideração celestial:

Temos visto como os motivos ou sem-razóes, por que os senhores desestimam e desprezam o nome, a cor, e a fortuna de seus escravos, são as mesmas razóes por que a Virgem, Senhora nossa, mais os estima, favorece e ama. E pois o mesmo desprezo entre os desprezadores foi causa da separação de uns e outros, dividindose brancos e pretos em duas irmandades do Rosário; muito temo que a mesma Senhora em castigo deste agravo da natureza, e seu, tenha aprovado a mesma separaçáo, e que nela fiquem de pior partido os brancos.

25. Há quatro acepçóes para essa palavra: I) aquele que participa das atividades, da amizade, do destino etc. de outrem; camarada, companheiro, parceiro; 2) título por que se tratavam reciprocamente os escravos africanos que tinham vindo da África na mesma embarcação; 3) irmão colaço ou de criação; 4) indivíduo nascido no mesmo ano, mês, dia e, se possível, hora que outra pessoa. 


\begin{abstract}
Seja este pois o fim desta separação de irmandades entre brancos e pretos. Os brancos e senhores náo se deixem vencer dos pretos, que seria grande afronta da sua devoção: os pretos e escravos procurem de tal maneira imitar os brancos e os senhores, que de nenhum modo consintam ser vencidos deles. E desta sorte, procedendo todos como filhos igualmente da Mãe de Deus, posto que diferentes na cor, não só conservarão a irmandade natural em que Deus os criou, mas alcançarão a sobrenatural e adotiva de seu Filho, herdeiro enquanto homem do cetro de Judas: Judam, et fratres ejus (IX).
\end{abstract}

No mundo de correspondências entre as distintas partes do universo, entre o físico e o espiritual, o divino e o humano (Saraiva 1944: 150) — fundamental aspecto compreensivo, mas inteiramente desconsiderado pelos analistas mais recentes ${ }^{26}$ Vieira concebe sua pregação. A Literatura agradece, pois o fim da rusticidade lusitana passa pelo transcendental.

\title{
5. A QUALIDADE LITERÁRIA DO INÍCIO DA MODERNIDADE
}

O salto qualitativo que a língua portuguesa sofreu entre os séculos XIV e XVI — como vimos, período da redaçáo da Crónica Geral de Espanha de 1344 e os Sermóes de Antônio Vieira - foi o mesmo que a língua catalã sofreu, embora um pouco mais prematuramente que em relação ao português. Para fazer apenas uma breve comparaçáo, a rudeza textual do Livro dos Feitos do rei Jaime I (I208-I276) é notável se comparada à graciosidade estilística de Curial e Güelfa (séc. xv), escrito anônimo que mescla de forma muito elegante o pano de fundo medieval com as novidades do Humanismo proveniente da Itália.

Para restringir-nos apenas à primeira e mais visível diferença literária entre ambas as obras, enquanto no Livro dos Feitos o tema do amor está basicamente restrito ao que o historiador Georges Duby (1990) designou como o amor feudal, o amor entre homens, do homem que se torna «homem de outro homem» - em Curial e Guelfa há a explosão do amor-paixão, amor-pulsão, amor-civilizacional que educou e domesticou os homens em seu tratamento para com as mulheres. ${ }^{27}$

Por exemplo, quando do encontro entre Jaime I e o rei de Navarra, Sancho VII, o Forte (II94-I234), há a afirmação do compromisso entre os reis através do amor feudal:

26. Como, por exemplo, Casimiro (200I).

27. Para o tema, ver Coutinho e Costa (2003) e Costa (2012). 
Ricardo da Costa \& Leticia Fantin Vescovi

Ainda suspira a última flor do Lácio?

Livro dos Feitos, cap. I20

En aquella sahó era viu lo rey Don Sanxo de Navarra, Naquela época, o rei Dom Sancho de Navarra ainda fill del rey Don Sanxo, qui fo lo meylor rey que anch estava vivo. Ele era filho do rei Dom Sancho, que foi o fos en Navarra. E el rey de Castela feya-li fer mal fer a melhor rei que existiu em Navarra. O rei de Castela lhe Don Lop Díez, senyor de Viscaya, sí que li havia tolts causava mal por meio de Dom Lope Dias, senhor de .II. o .III. castels dels seus. E el rey de Navarra enviăns Vizcaya, o qual the havia tomado dois ou três castelos. missatge que si nós volíem haver amor ab ell, que ell O rei de Navarra enviou uma mensagem perguntando la hauria ab nós e que ell nos faria tanta de gràcia e de que, caso nós desejássemos compartilhar o nosso amor amor, que anc rey no la féu a altre major. com ele, ele o faria conosco, e nos proporcionaria tanta (Jaume I 20I0: 223) graça e amor como nunca outro rei fez. ${ }^{28}$

Por sua vez, em Curial e Güelfa o próprio tema que serve de pano de fundo para o desenrolar da história é o amor, e o autor por trás da passagem de abertura da novela, Petrarca (I304-I374), ${ }^{29}$ pai dos humanistas.

\section{Curial e Guelfa, Prólogo}

$[\mathrm{O}$,$] quant és gran lo perill, quantes són les sol-licituts \mathrm{Oh}$ ! Quão grande é o perigo, quantas são as solicitudes e les congoxes a aquells qui $\cdot s$ treballen en amor! Car, e engústias daqueles que sofrem por amor! Pois, embora posat que alguns amats de la fortuna, aprés de infinits alguns amados pela Fortuna, depois de infinitos inforinfortunis, sien arribats al port per ells desijat, tants túnios, tenham chegado ao tão desejado porto, tantos emperò són aquells qui rahonablement se'n dolen, que são os que consideravelmente sofrem, que mal posso anvides pusch creure que entre mil desaventurats se'n tròpia un que hage amenada la sua causa a gloriosa fi.

E, si ab dret juyhí serà esguardat lo cas següent, jatsia que seran molts aquells qui diran que ells voldrien que axí $\cdot 1 s$ prengués de les sues amors, emperò, sabent la certenitat de les penes de les quals aquella dolçor amarga és tota plena, e no havent certenitat de la fi si serà pròspera $\mathrm{o}$ adversa, se deurien molt guardar de metre's en aquest amorós ans dolorós camí.

E per ço us vull recitar quant costà a un gentil cavaller e a una noble dona lo amar-se l'un a l'altre, e com ab gran treball e pena, e seguits de molts infortunis, aprés lonch temps aconseguiren lo guardó de lurs treballs.

(Curial e Güelfa 2007: 43) crer que, dentre mil desventurados, se encontre um que tenha conduzido sua causa a glorioso fim.

E se julgamos corretamente que será bem apreciado o caso seguinte, embora sejam muitos aqueles que diráo que desejariam que seus amores fossem assim acolhidos, contudo, conhecendo a certeza das penas das quais aquela doçura amarga é repleta, e não havendo a certeza se o fim será próspero ou adverso, deveriam muito considerar antes de se colocarem nesse caminho mais doloroso que amoroso.

Por isso desejo narrar o quanto custou a um gentil cavaleiro e a uma nobre dama amarem-se um ao outro, e como, com grande sofrimento e pena, seguidos de muitos infortúnios, só depois de muito tempo conseguiram o galardáo de seus sofrimentos.

(Curial e Güelfa 20II: 82)

28. A tradução é de Ricardo da Costa, com base na edição de Ferrando. 29. Epistolae familiares (Rerum familiarum libri, I325-I37I, IV, I2, 29) 
A polidez como a abertura petrarquiana de Curial e Guelfa é desenvolvida está bastante distante da secura e objetividade do texto do rei Jaime I no Livro dos Feitos. Do mesmo modo, a crueza do texto do conde de Barcelos dista muitíssimo da riqueza estilística do Sermão de Antônio Vieira, baseado primacialmente nos clássicos grecoromanos (especialmente Cícero) somados à tradição patrística e medieval (naquele sermão acima comentado, Vieira cita nominalmente Beda e Cassiodoro). A única diferença, grosso modo, é a precocidade da desenvoltura linguística e cultural castelhana em relação à portuguesa, embora os frutos mais maduros de ambas as línguas (Camões e Cervantes) tenham desabrochado aproximadamente no mesmo período histórico.

\section{O CANTO DE CISNE DAS MUSAS}

Em que pese o fato de ter nascido no bojo do cientificismo do século xIx, o movimento parnasiano parisiense trouxe de volta o culto ao classicismo, fonte perene e inesgotável da civilização ocidental (Curtius 1996).

Esse eterno retorno aos clássicos marcou profundamente a história da literatura ocidental. Desde a Idade Média, mais precisamente desde o Renascimento carolíngio, o recurso aos clássicos foi levado a cabo pela maior parte dos grandes escritores. E justamente a decadência da cultura ocidental começou quando os clássicos passaram, gradativamente, a serem deixados de lado. Mas esse é outro assunto.

Para o tema que aqui nos interessa, gostaria de concluir esse breve périplo com um grande poeta brasileiro, Olavo Bilac (I865-1918), cujo movimento, o Parnasianis$m o$, oriundo de Paris da segunda metade do século XIX, ${ }^{30}$ propunha a defesa da arte pela arte, a beleza da forma (o chamado mundo das formas), da estética, da ordem das palavras. Concisão. Rigor. Cultivaram por isso a perfeição — formal e vocabular seguindo assim a mais pura tradição clássico-poética.

O movimento foi muitíssimo popular no Brasil, e chegou inclusive a influenciar a criação da Academia Brasileira de Letras. A atitude dos poetas - denominada neo-

30. O ponto de partida do movimento foi a publicação da antologia Parnase contemporain (uma trilogia editada por Alphonse Lemerre em I838-I9I2 e publicada em I866, I87I e I876), que reunia composiçóes de vários autores com, por exemplo, de Theóphile Gautier (I8II-I872), Théodore de Banville (I823-I89I) e Leconte de Lisle (I8I8-I894). 
parnasiana — é a que desejo destacar, pois os conecta com a tradição clássico-literária universal e, indiretamente, com o humanismo catalão expresso em Curial e Güelfa. ${ }^{31}$ Embora profundamente antipático ao Parnasianismo, Alfredo Bosi (I970: 226) definiu Bilac como o mais antológico dos poetas brasileiros. Seu amor pela palavra, por sua beleza intrínseca, que deve ser buscada a todo momento pelo poeta, está muito bem sintetizada no serviço à Deusa Forma no poema Profissão de Fé:

\author{
Invejo o ourives quando escrevo: \\ Imito o amor \\ Com que ele, em ouro, o alto relevo \\ Faz de uma flor. \\ Imito-o. E, pois, nem de Carrara \\ A pedra firo: \\ $\mathrm{O}$ alvo cristal, a pedra rara, \\ O ônix prefiro. \\ Por isso, corre, por servir-me, \\ Sobre o papel \\ A pena, como em prata firme \\ Corre o cinzel. \\ Corre; desenha, enfeita a imagem, \\ A idéia veste: \\ Cinge-lhe ao corpo a ampla roupagem \\ Azul-celeste. \\ Torce, aprimora, alteia, lima \\ A frase; e, enfim, \\ No verso de ouro engasta a rima, \\ Como um rubim. \\ Quero que a estrofe cristalina, \\ Dobrada ao jeito \\ Do ourives, saia da oficina \\ Sem um defeito:
}

3I. Em contrapartida, foi essa mesma atitude que fez com que os modernistas se revoltassem contra o Parnasianismo. Por exemplo — e para ficar apenas no mais elegante — o poeta Mário de Andrade (I893-I945) compôs o que chamou de "elogio fúnebre dos mestres do passado", série de artigos publicados no Jornal do Comércio (192I). 
E que o lavor do verso, acaso,

Por táo subtil,

Possa o lavor lembrar de um vaso

De Becerril.

E horas sem conto passo, mudo,

O olhar atento,

A trabalhar, longe de tudo

$\mathrm{O}$ pensamento.

Porque o escrever - tanta perícia,

Tanta requer,

Que oficio tal... nem há notícia

De outro qualquer.

Assim procedo. Minha pena

Segue esta norma,

Por te servir, Deusa serena,

Serena Forma!

A palavra exprime as ideias e as coisas. Além de significá-las verbalmente, ela deve representá-las do modo mais belo possível. Correto, verdadeiro, conciso, puro. A intensidade do brilho da poesia de Bilac é posta em um ritmo neoclássico que, de acordo com Bosi (I996: 228), está próximo de Bocage (I765-I805) e de Camóes.

Os trinta e cinco sonetos de Via Láctea têm algumas das passagens poéticas mais deslumbrantes de Olavo Bilac. Citaremos apenas um, o de número XIII, que tem uma relação direta, alusiva, com a forma de os medievais contemplarem o universo ${ }^{32}$ (além do tema principal subjacente, o amor sensual, diretamente ligado ao amor cortês medieval):

Ora (direis) ouvir estrelas! Certo

Perdeste o senso!» E eu vos direi, no entanto,

Que, para ouvi-las, muita vez desperto

E abro as janelas, pálido de espanto...

E conversamos toda a noite, enquanto

A via-láctea, como um pálio aberto,

Cintila. E, ao vir do sol, saudoso e em pranto,

Inda as procuro pelo céu deserto.

32. Vali-me do soneto em Costa (2002). 
Direis agora: «Tresloucado amigo!

Que conversas com elas? Que sentido

Tem o que dizem, quando estão contigo?

E eu vos direi: «Amai para entendê-las!

Pois só quem ama pode ter ouvido

Capaz de ouvir e de entender estrelas

A capacidade dos parnasianos de sintetizar e compactar o ideal de beleza poética, seu amor pela perfeição do verso, pela concisão, têm relação direta com as raízes clássicas do movimento, espécie de classicismo renascido através do ideal estético daqueles poetas — último renascimento, até os dias de hoje — mas também à alusão ao monte Parnaso, pátria dos poetas gregos, cume da expressão verbal, morada das Musas. ${ }^{33}$ A menção às Musas (Calíope, ${ }^{34}$ Clio, ${ }^{35}$ Euterpe,${ }^{36}$ Tália, ${ }^{37}$ Melpômene, ${ }^{38}$ Polímnia,,${ }^{39}$ Erato, ${ }^{40}$ Terpsícore $^{41}$ e Urânia ${ }^{42}$ ) é um dos pontos altos de Curial e Güelfa. Em seu Livro III, há um belíssimo parágrafo em que o mito é explicado ao leitor:

33. O tema mitológico das Musas no Parnaso ultrapassou o universo literário. Nas artes, por exemplo, os séculos XVI-XVII presenciaram um verdadeiro boom a respeito: Holbein, o Jovem (I497-I543), Apolo e as Musas no Parnaso (I535); Maerten van Heemskerck (I498-I574), Apolo e as Musas (I560); Nicolas Poussin (I594-I665), Apolo $e$ as Musas (I635); Simon Vouet (I590-I649), Parnaso ou Apolo e as Musas (I640); Claude Lorrain (c. I602-I682), Apolo e as Musas no Monte Helion (I680). No século XIX, um dos últimos suspiros artísticos: Gustave Moreau (I826-1898), Apolo e as Nove Musas (1856), pouco antes da irrupção do Parnasianismo em França.

34. Musa da eloquência e da poesia épica. A ela os poetas se dirigem em busca de inspiraçáo.

35. A que celebra. Canta a glória dos guerreiros e as conquistas de um povo. Patrona da História.

36. A doadora de prazeres. Preside à Música. Inventora da flauta e de outros instrumentos de sopro.

37. Preside a Comédia e a Poesia.

38. Musa da Tragédia, mas também do canto e da harmonia musical.

39. A de muitos hinos. Musa da Oratória e do Ditirambo (canto coral ao deus Dionísio).

40. A amável. Musa da poesia lírica.

4I. Musa da dança e dos coros dramáticos.

42. Musa que presidia a Astronomia e as Ciências Exatas. 
Ricardo da Costa \& Leticia Fantin Vescovi

Ainda suspira a última flor do Lácio?

\begin{tabular}{|c|c|}
\hline \multicolumn{2}{|c|}{ Curial e Güelfa, Livro III, Proêmio } \\
\hline $\begin{array}{l}\text { En aquest tercer libre, per ço com fa menció de les Muses, } \\
\text { deus pressupondre que los poetes han fingit nou Muses, en } \\
\text { forma de nou dones o donzelles, habitants en Monte Parnaso } \\
\text { e colents Elicona; e foren per ells appellades Calíope, Clio, } \\
\text { Euterpe, Talia, Melipòmene, Pol-límia, Ėrato, Tersícore e } \\
\text { Urània. E sobre aquestes fabuliza Ovidi, en lo quint libre, que } \\
\text { altres nou germanes, nades en Grècia, de Píreus, pare seu, e } \\
\text { de mare Evipta —e per ço són dites Pièrides-, aprengueren } \\
\text { sonar e cantar maravellosament, e per rahó de aquella delec- } \\
\text { table sciència que és appellada música, de la qual per ventura } \\
\text { elles no eren tan grans maestres com pensàvan, devengueren } \\
\text { molt superbes e vanaglorioses, en tant que, menyspreant } \\
\text { totes les altres persones expertes en aquella art, se volgueren } \\
\text { no solament parificar ab les Muses, ans encara subpeditar-les. } \\
\text { E axí, oydores per los déus, a batalla o disputa vengueren en } \\
\text { aquesta manera: que les dites Muses diputaren una d'elles, e } \\
\text { les Pièrides, semblantment, altra de lurs germanes, les quals } \\
\text { disputassen, e aquella que mills ho faria guanyàs per a la sua } \\
\text { part la victòria. Per què, oydes les parts, fonch judgat Calíope } \\
\text { haver cantat e sonat mills que la altra que les Pièrides havien } \\
\text { elegida. Tantost, les dites Pièrides foren per los déus convertides } \\
\text { en piques, que en comun lenguatge cathalà són dites garces, e } \\
\text { són ocells garruladors, e aprenen parlar en totes lengües ço que } \\
\text { ls mostren, emperò /f.I4sv/ no saben ni entenen ço que dien. }\end{array}$ & 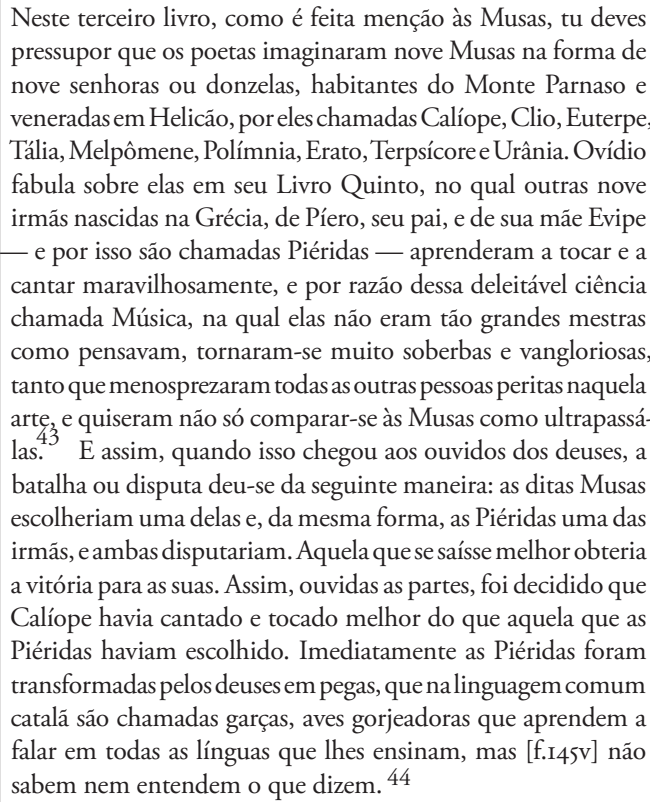 \\
\hline $\begin{array}{l}\text { E, quant a l'integument d'aquesta faula, diu Fulgenci que nou } \\
\text { Muses són dites nou consonàncies de la veu humana, eles nou } \\
\text { Pièrides, nou dissonàncies. E diu Papias que aquestes Muses } \\
\text { són dites filles de Jovis e de Juno, per rahó com tota veu de } \\
\text { vent e de aygua se fa. E Musa és dita a moys, grech, que és } \\
\text { aygua, perquè tot so musical de ayre e de aygua s'engendra, } \\
\text { car no pot alguna veu sonar sens vent e sens aygua e lurs } \\
\text { moviments; e axí, de aquestes dues coses totes les forces del } \\
\text { cant e de la modulació vénen. }\end{array}$ & $\begin{array}{l}\text { Quanto ao significado dessa fábula, diz Fulgêncio } 45 \text { que } \\
\text { as nove Musas correspondem às nove consonâncias da voz } \\
\text { humana, e as nove Piéridas às nove dissonâncias. Papias } 46 \\
\text { diz que estas Musas se consideram filhas de Júpiter e de Juno, } \\
\text { pois toda voz se faz com vento e água, já que a palavra Musa } \\
\text { vem do grego moys, que significa água, porque todo som } \\
\text { musical se engendra do ar e da água e nenhuma voz pode } \\
\text { soar sem vento, água, e seus movimentos. Assim, dessas duas } \\
\text { coisas procedem todas as forças do canto e da modulação. }\end{array}$ \\
\hline
\end{tabular}

43. As Piéridas eram as nove filhas de Píero e Evipe. Dotadas de grande talento musical, desafiaram as Musas para um concurso de canto. Foram vencidas e transformadas em pássaros.

44. A garça é um animal citado várias vezes pelo filósofo Ramon Llull (I232-I3I6) em suas obras. Por exemplo, na Árvore da Ciência (I295-I296) há um exemplum em que uma garça tenta inutilmente aconselhar uma pomba, e, no fim, é comida por dois símios. Ramon Llull, «Árvore Exemplifical. Dos provérbios do tronco Imperial». In: Obres de Ramon Llull (ORL, ed. S. Galmés e outros). Palma de Mallorca: vol. XII, tomo II, I923, p. 375-377. Essa passagem foi abordada em Costa (2000: 2I6-22I).

45. Fábio Plancíades Fulgêncio (séc. v-VI) foi um gramático latino-africano. Seu estilo pomposo (africano tardio) é inspirado em Apuleio de Madaura (c. I25-I80), Tertuliano (c. I60-220) e Marciano Capella (séc. v).

46. São Papias de Hierápolis (c. 69-I55) foi bispo de Hierápolis (Frígia Pacatiana) e um dos padres apostólicos da Igreja Católica. Santo Ireneu de Lião (c. I3O-202) afirma que ele foi companheiro do bispo Policarpo de Esmirna (c. 70-I55), consequentemente discípulo do apóstolo João. 
Enquanto a expressáo literária da língua portuguesa alcançou seu clímax com Antônio Vieira, a poética chegou ao seu ápice com os parnasianos, canto de cisne da última flor do Lácio. A partir de então, a busca pelo Belo deu lugar aos diferentes experimentalismos do Modernismo (I922) e sua posterior ramificação em pelo menos mais duas geraçôes (1930-1945 e 1945-1980). Além disso, enquanto o recurso literário às Musas na novela catalá projetou-a para o seu futuro - o Humanismo que desabrochava na Itália (Butiñá Jiménez 2000; Butiñá Jiménez e Cortijo Ocaña 20II) — a referência dos parnasianos ao poético Parnaso grego representou a volta a um passado que morria naquele presente. Futuro do passado no século XV e passado do presente no XIX, o fato é que a referência aos clássicos por parte da literatura foi sepultada no ocaso do século $\mathrm{xx}$, tempo destruidor-mor de todas as tradiçóes artísticas, época das rupturas, das revoluçốes permanentes e soluçóes imanentes.

\section{CONCLUSÃO}

Nada que é belo é indispensável para a vida. Caso suprimíssemos as flores, o mundo não sofreria materialmente. Não obstante, quem desejaria que não houvesse mais flores? [...] Há no mundo algum utilitarista capaz de arrancar um canteiro de tulipas para ali plantar couveflores? E para que serve a beleza das mulheres? Uma mulher medicamente bem-formada e capaz de procriar será sempre boa para os economistas por mais que não seja muito graciosa. E para que servem a Música, a Pintura? Quem seria louco o suficiente para preferir Alexis Carrel a Wolfgang Amadeus Mozart e o inventor da mostarda a Michelangelo? [...] Tudo o que é útil costuma ser feio, já que é a expressão de alguma necessidade, e as do homem são ignóbeis e repugnantes, como sua pobre e doente natureza.

Théophile Gautier (I8II-I872), Mademoiselle de Maupin (Prefácio).

No Brasil hodierno, o amor à palavra praticamente desapareceu. Os experimentos sociais propostos pela filosofia pedagógica construtivista, principalmente a partir da década de 70, principalmente a partir do sucesso da Pedagogia do Oprimido (1970), resultaram em um analfabetismo funcional que beira as raias da demência. Incapazes de apreciar os clássicos, impossibilitados de sorver as suaves filigranas da alta cultura, os professores recém-egressos das universidades mal sabem conjugar verbos. Apáticos, sequer anseiam. Vocabulário? Para quê? As palavras belas, desditosas, se transformaram em opressoras das «classes populares».

Os séculos que presenciaram a lenta (porém constante) construção da última flor do Lácio desembocaram, na segunda metade do século xx, em décadas de acele- 
rada destruição. Nihilismo cultural. Imagino Vieira a regurgitar na cova. Desolados, verdadeiramente desconsolados, os exíguos amantes da arte, da literatura, solitários, contemplam, como O Viajante sobre o Mar de Névoa (c. I818), de Caspar David Friedrich (I774-1840), as brumas da decadência cultural desse início de milênio.

Aceitar o convite de para escrever esse opúsculo, apesar de ter nos proporcionado a inenarrável alegria do conhecimento da história da literatura comparada, em contrapartida, acrescentou mais uma amarga gota de melancolia à noss'alma, pela consciência de chafurdar em tempos ética e culturalmente sombrios. Viva o cataláo medieval e moderno, o espanhol áurico e o português barroco. Desfrutá-los é como saborear um bom vinho, degustação que, além de inebriar, momentaneamente me suprime dos tempos modernos.

\author{
Ricardo Luiz Silveira da Costa \\ ricardo@ricardocosta.com \\ Leticia Fantin Vescovi \\ leticiafbs@hotmail.com \\ Universidade Federal do Espirito Santo, Brasil
}

\title{
BIBLIOGRAFIA
}

Baldinger, K. (1963) La formación de los dominios lingüisticos en Ia Peninsula Ibérica, Madrid, Editorial Gredos («Biblioteca Románica Hispánica»).

Bosı, A. (1970) História concisa da literatura brasileira, São Paulo, Cultrix.

— org. (20II) Essencial Padre Antônio Vieira, São Paulo, Penguin Classics / Companhia das Letras, pp. 207-245.

Butiñá Jiménez, J. (2000) Tras los orígenes del Humanismo: "El Curial e Güelfa», Madrid, UNED.

Butiñá Jiménez, J. \& A. Cortijo Ocaña, eds. (2OII) L'Humanisme a la Corona d'Aragó (en el context hispànic i europeu), USA («Scripta Humanistica», I65).

Casimiro, A. (200I) "Quatro visóes do escravismo colonial: Jorge Benci, Antônio Vieira, Manuel Bernardes e João Antônio Andreoni», Politeia: História e Sociedade, Vitória da Conquista, «vol.» I, n. I, pp. I4I-I59.

Cintra, L. (199i) Crónica Geral de Espanha de 1344, Lisboa, Imprensa Nacional / Casa da Moeda, «vol.» 4. 
Costa, R. (20I2) «A imagem da mulher medieval em O Sonho (1399) e Curiale Guelfa (c. I460)», Site NetHistória, Brasília, Sessão Artigos. [Disponível em: <http://www. nethistoria.com.br/secao/artigos/IIo2/a_imagem_da_mulher_medieval_em_o_ sonho_1399_e_curial_e_guelfa_c_I460_/ >.]

- (2000) «A Árvore Imperial. Um Espelho de Príncipes na obra de Ramon Llull (I232-I316)», Niterói, tese de doutorado.

— (2002) «Olhando para as estrelas, a fronteira imaginária final. Astronomia e Astrologia na Idade Média e a visão medieval do Cosmo", Dimensóes. Revista de História da UFES I4. Dossiê Territórios, espaços e fronteiras, Vitória, EDUFES, pp. 48I-50I. — (2008) "Para que serve a História? Para nada...», Sinais 3, vol. I (junho), Vitória, Ufes, Centro de Ciência Humanas e Naturais, pp. 43-70.

Costa, R. \& B. Dantas (20I3) «'A falsidade dos judeus é grande': uma representação de judeus nas Cantigas de Santa Maria (séc. XIII)», Anais do X EIEM, Brasília, no prelo. [Disponível em: $<$ http://www.ricardocosta.com/artigo/falsidade-dos-judeus-e-grande-uma-representacao-de-judeus-nas-cantigas-de-santa-maria-sec $>$.] - (no prelo) «Bondade, Justiça e Verdade. Três virtudes marianas nas Cantigas de Santa Maria no Livro de Santa Maria, de Ramon Llull». [Disponível em: <http://www. ricardocosta.com/artigo/bondade-justica-e-verdade-tres-virtudes-marianas $>$.]

Coutinho, P. \& R. Costa (2003) «Entre a Pintura e a Poesia: o nascimento do Amor e a elevação da Condição Feminina na Idade Média», Apuntes sobre familia, matrimonio y sexualidad en la Edad Media, Mar del Plata, Grupo de Investigaciones y Estudios Medievales, Universidad Nacional de Mar del Plata («Colección Fuentes y Estudios Medievales» I2), pp. 4-28.

Curial e Güelfa (2007 [ $\mathrm{I}^{\mathrm{a}}$ ed. c. I460]). Introducció i edició filològica per Antoni Ferrando. Toulouse, Anacharsis Éditions.

- (20II [ $\mathrm{I}^{\mathrm{a}}$ ed. c. I460]). Traduçáo e notas de Ricardo da Costa. University of California, Santa Barbara, Publications of eHumanista.

Curtius, E. R. (1996) Literatura Européia e Idade Média Latina, São Paulo, HUCITEC. DE los Ríos, J. A. (I86I) Historia critica de la literatura española, Madrid, Impr. de J. Rodriguez.

Dias, J. (1948) Os arados portugueses e suas prováveis origens, Coimbra.

Duby, G. (1988) A Europa na Idade Média, São Paulo, Martins Fontes.

- (1990) História da vida privada 2. Da Europa feudal à Renascença, São Paulo, Companhia das Letras. 
Frappier, J. (1973) Amour courtois et Table Ronde, Genève, Droz.

Freire, P. (2005 [ $\mathrm{I}^{\mathrm{a}}$ ed. 1968]) Pedagogia do Oprimido, Rio de Janeiro, Paz e Terra.

Grégoire de Tours. (I999 [ $\mathrm{I}^{\mathrm{a}}$ ed c. 59i]) Histoire des Francs, Paris, Les Belles Lettres. Hatem, J. (20II) Sobreamor. Ausiàs March. Ibn Zaydûn, Ibn 'Arabî, Ramon Llull, Santa Coloma de Queralt, Obrador Edèndum.

Jaime I (20Io) Livro dos Feitos. Apres., trad. e notas de Luciano José Vianna e Ricardo da Costa. São Paulo, IBFCRL.

- (2010) Llibre dels feits del rei em Jaume (estudis i edició a cura d'Antoni Ferrando i Francés $i$ Vicent Josep Escartí i Soriano), València.

Lapa, M. R. (198I) Liçóes de literatura portuguesa: época medieval, Coimbra, Coimbra Editora.

Le Goff, J. (1983) A civilização do Ocidente medieval, Lisboa, Editorial Estampa, «vol.» I.

Llull, Ramon. (1923) «Arbre Exemplifical. Dels proverbis del tronc Imperial», Obres de Ramon Llull (ORL, ed. S. Galmés e outros), Palma de Mallorca, vol. 7, tomo II, pp. 375-377.

Maleval, M., L. Mongelli \& Y. Vieira (1992) A literatura portuguesa em perspectiva: Trovadorismo, Humanismo, São Paulo, Atlas, «vol.» I.

Moralejo, J. L. (1973) «El cancionero erótico de Ripoll en el marco de la lírica mediolatina", Prohemio, IV.

- (1986) Cancionero de Ripoll. Carmina Rivipullensia, Barcelona.

Oliveira, F.. (1974 [Iª ed. 1536]) A gramática da língua portuguesa, Lisboa, Imprensa Nacional.

Petrônio (2004) Satyricon (tradução e posfácio de Sandra Braga Bianchet), Belo Horizonte, Crisálida.

Puyol, J. (1906) El Arcipreste de Hita: estudio crítico, Madrid, Sucesora de M. Minuesa de los Ríos.

Ruiz-Domènec, J. E. (20II) "Wolfgang Amadeus Mozart: el hechizo de la música», Personajes intempestivos de la Historia, Madrid, Gredos, pp. 25I-283

Saraiva, A. J. (1988) O Crepúsculo da Idade Média em Portugal, Lisboa, Gradiva.

- (1994) A cultura em Portugal, Lisboa, Gradiva Publicaçôes.

Scruton, R. (2009) Beleza, Lisboa, Guerra e Paz Editora.

Serta. Revista Iberorrománica de Poesía y Pensamiento Poético 10, (2008-2009), Universidad Nacional de Educación a Distancia, pp. I9I-192.

Spina, S. (1996) A lírica trovadoresca, São Paulo, Edusp. 